\title{
Adipose Tissue-Derived Stem Cells and Their Application in Bone and Cartilage Tissue Engineering
}

\author{
Tommaso Rada, B.Sc., Rui L. Reis, Ph.D., and Manuela E. Gomes, Ph.D.
}

The adipose tissue was considered a reserve of energy until the '80s, when it was found that this tissue was involved in the metabolism of sex steroids such as estrogens. From then on, the importance attributed to this tissue radically changed as it was then considered an active organ, involved in important functions of the human body. In 2001, for the first time, the existence of stem cells within this tissue was reported, and since then, this tissue has been gaining an increased importance as a stem cell source for a wide range of potential applications in cell therapies and/or tissue engineering and regenerative medicine strategies, mainly due to its wide availability and easy access. This manuscript provides an overview on adipose stem cells (i.e., adipose tissue-derived stem cells, ASCs) considering the tissue of origin, the niche of the ASCs, and their phenotype in all aspects. In this paper it is also discussed the markers that have been used for the characterization of these cells, their differentiation properties, and their immunological reactivity, reporting studies from 2001 until this date. The ASCs are also compared with bone marrow stem cells (BMSCs), until now considered as the gold standard source of stem cells, underlining the common characteristics and the differences between the stem cells obtained from these two sources, as well as the advantages and disadvantages of their potential use in different applications. Finally, this review will also focus on the potential application of ASCs in tissue engineering applications, particularly in the regeneration of bone and cartilage, commenting on the progress of this approach and future trends of the field.

\section{Introduction}

T

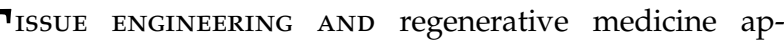
proaches offer the possibility to help in the regeneration of tissues damaged by disease or trauma. ${ }^{1,2}$ This is achieved through the use of degradable biomaterials that serve as temporary scaffold for transplanted cells to attach, grow, and maintain differentiated functions. ${ }^{2}$ Therefore, a major consideration for the most widely studied tissue engineering approaches, which are based on seeding and in vitro culturing of cells within the scaffold before implantation, is the cell source and the ability to control cell proliferation and differentiation. The recent identification of human embryonic stem cells-cells that can give rise to essentially all cell types in the body, depending on the culturing conditions-offers probably the most exciting alternative source of cells for tissue engineering. However, researchers are still far from being able to control the differentiation of embryonic stem cells in culture. In addition, the research on embryonic cells brings up a range of ethical, political, and legislative problems that differ from country to country. ${ }^{3,4}$ This has driven researchers to actively investigate alternative cell sources, such as the adult stem cells. These are undifferentiated cells that occur in differentiated tissues theoretically in the adult body but in fact from birth. They can renew themselves in the body, making identical copies of themselves for the lifetime of the organism, or become specialized to yield the cell types of the tissue of origin. Thus, they are presently considered as multipotent stem cells. ${ }^{5,6}$ Now, several sources of adult stem cells have been identified, but bone marrow has been the most widely studied for bone tissue engineering applications. ${ }^{7-14}$ Bone marrow stem cells (BMSCs) consist of a heterogeneous cell population, also known as mesenchymal stem cells, that contributes to the generation of mesenchymal tissue such as bone, cartilage, and muscle. Bone marrow has also been considered a main source of stem cells for therapeutic purposes, as it has high differentiation potentials and low morbidity during harvesting. However, for example, the osteoprogenitor population tends to decrease in aged and osteoporotic humans. Also, excessive proliferation in vitro would decrease their osteogenic potential. Because a high cell density is required to yield a successful outcome of tissue-engineered bone, an alternative source of

3B's Research Group-Biomaterials, Biodegradables and Biomimetics, Department of Polymer Engineering, University of Minho, Braga, Portugal.

IBB-Institute for Biotechnology and Bioengineering, PT Government Associated Laboratory, Braga, Portugal. 
adult stem cells that could be obtained in larger quantities, under local anesthesia and with minimal discomfort, would be advantageous. Recent studies indicated that nascent stem cells exist within other adult tissues, such as the adipose tissue. In fact, it has been demonstrated that adipose tissue-derived stem cells (ASCs) possess multiple differentiation capacities. ${ }^{5}$ Additionally, adipose tissue is probably the most abundant and accessible source of adult stem cells, and thus it holds great promise for use in tissue repair and regeneration. Nevertheless, ASCs and marrow-derived stem cells are remarkably similar with respect to growth and morphology, displaying fibroblastic characteristics, with abundant endoplasmic reticulum and large nucleus relative to the cytoplasmic volume. ${ }^{5,15,16}$ Other common characteristics of ATSCs and BMSCs can be found in the transcriptional and cell surface profile. In fact, much of the research carried out so far with ASCs has been based on methods previously established for BMSCs. ${ }^{5,15,16}$ Nevertheless, to take full advantage of this cell source for tissue engineering applications, it is necessary to learn more about this cell source and understand its specific characteristics, which will certainly indicate that future research on this cell source will need to address several issues, such as, the differences found in the harvesting methods, differences in fat tissue derived from different anatomic sites (e.g., abdomen, thighs, infrapatellar, visceral, and subcutaneous), and the heterogeneity of the cell population that is obtained using the isolation methods most commonly used do far. This manuscript provides an overview on these aspects, focusing on the potential of ASC in bone and cartilage tissue engineering.

\section{Main Aspects of Adipose Tissue Physiology}

The adipose tissue is composed of cells-the adipocytesorganized in multidepots. ${ }^{17,18}$ However, only one-third of the adipose tissue contains adipocytes, the remaining tissue being composed of small blood vessel, nerve tissue, fibroblasts, preadipocytes, and adult stem cells. ${ }^{3}$ The adipocytes can be white or brown, defining the type of the adipose tissue as white adipose tissue (WAT) or brown adipose tissue (BAT), respectively. ${ }^{17}$ The WAT is characterized by an ivory/ yellow color, while the BAT appears brown. In neonates, the BAT can be found in several parts of the body ${ }^{19-21}$; however, with aging, brown adipocytes undergo a morphologic transformation, which is characterized by an accumulation of lipids; the brown adipocytes become unilocular and lose the ultrastructural and molecular proprieties that define them. ${ }^{22,23}$ As a consequence, it is not possible to find discrete collections of this type of adipose tissue in adults.

The development of white adipocytes begins in the embryonic stage, ${ }^{24}$ but it is only after the birth that the majority of the differentiation process occurs. ${ }^{25}$ The WAT can be found in several anatomic depots, but there are two main anatomic subdivisions, each with unique metabolic, endocrine, paracrine, and autocrine properties: the intraabdominal or visceral adipose tissue and the subcutaneous adipose tissue. The subcutaneous adipose tissue is divided in two different layers: the superficial subcutaneous adipose tissue and the deep subcutaneous adipose tissue. ${ }^{26}$ The visceral fat is divided into intraperitoneal and retroperitoneal adipose tissue. The intraperitoneal fat comprises the majority of the visceral fat. ${ }^{27-29}$ WAT depots have also been found around other organs, such as the heart, kidney, and genitalia, and bone marrow. ${ }^{17}$ It is particularly important to underline that the metabolic characteristics of each type of depot are deeply influenced by the anatomic part where they are found, and therefore, BAT and WAT may differ significantly depending on the anatomical parts of origin.

The most well-known adipocytokine is leptin. Leptin has a wide spectrum of endocrine and paracrine functions such as appetite regulation, modulation of hepatic and adipose tissue-related insulin secretion and activity, and modulation of steroid in the ovaries and adrenal cortex. ${ }^{30}$ Other important adipocytokines include adipsin, adiponectin, and tumor necrosis factor- $\alpha .^{31-33}$

\section{Stem Cells from Adipose Tissue}

\section{Historical perspective of ASCs}

Zuk et al. ${ }^{34,35}$ were the first to report the presence of stem cells in the adipose tissue (i.e., the ASCs), publishing two important papers between 2001 and 2003, the first demonstrating the differentiation potential of these cells ${ }^{34}$ and the second one showing the presence of all the proteins recognized as markers for the stem cells. ${ }^{34,35}$ However, even though Zuk was the first one to formally describe these cells from the adipose tissue as stem cells, previous reports demonstrated the capability of preadipocytes to exhibit an osteogenic potential. ${ }^{36-38}$

After the studies published by Zuk, several further publications, ${ }^{5,15,39-44}$ resulting from research carried out by different groups, showed the differentiation potential of the ASCs and described the presence/absence of several markers. Nowadays, it has been described the extraction of ASCs from multiple species, including rats, rabbit, ${ }^{45,46}$ dogs, $^{47-49}$ pigs, ${ }^{50-53}$ and of course humans, ${ }^{54,55}$ as well as the capacity of these cells to differentiate into the osteogenic, ${ }^{16,53,56-65}$ chondrogenic, ${ }^{16,61,62,66-70}$ myogenic, ${ }^{71,72}$ neuronal, ${ }^{52,73,74}$ and even cardiomyocytic lineages ${ }^{75,76}$ (Table 1).

The nomenclature is part of the history of these stem cells. As it happens frequently in rapidly developing scientific fields, stem cells from adipose tissue have been named with a very wide variety of terms. The cells isolated from the digestion of the adipose tissue with collagenase have been termed adipose stem/stromal cells (ASCs), adipose-derived adult stem (ADAS) cells, adipose-derived stromal cells (ADSCs), adipose mesenchymal stem cells (AdMSCs), processed lipoaspirated cells (PLA), and preadipocytes. The use of multiple nomenclatures obviously created confusion within this research field. Finally, the researchers who participated in the annual conference of the International Fat Applied Technology Society, held in Pittsburgh in 2004, have reached a consensus, adopting the designation of adipose stem cells (ASCs).

\section{Localization of ASC in fat tissue}

As mentioned before, there are several adipose depots all around the body, and each one situated in a specific niche. As a consequence, the ASCs isolated from one depot can differ from the ones isolated from other depot located in a different anatomical areas, as well as the cells isolated from WAT can have different characteristics with respect to the ones isolated from brown adipose tissue. The WAT and the BAT differ in the number of ASCs that can be isolated and in 
Table 1. Animal Models and Enzymes Used for Adipose Stem Cell Isolations Described in Literature

\begin{tabular}{|c|c|c|c|c|}
\hline Species of origin & Location of origin & Isolation procedure & Differentiation & Reference \\
\hline Human & $\begin{array}{l}\text { Lipoaspirated } \\
\text { subcutaneus }\end{array}$ & Collagenase type I & $\begin{array}{l}\text { Adipogenic, chondrogenic, } \\
\text { osteogenic, and myogenic }\end{array}$ & 34 \\
\hline Human & $\begin{array}{l}\text { Subcutaneus } \\
\text { adipose tissue }\end{array}$ & Collagenase type I & Adipogenic and osteogenic & 42 \\
\hline Human & $\begin{array}{l}\text { Lipoaspirated } \\
\text { subcutaneus }\end{array}$ & Collagenase type I & None & 43 \\
\hline Rabbit & $\begin{array}{l}\text { Visceral and subcutaneus } \\
\text { adipose tissue }\end{array}$ & Collagenase type I & Osteogenic & 47 \\
\hline Dog & Inguinal fat pad & Collagenase type I & Osteogenic & 49 \\
\hline Human & Lipoaspirated & & & 51 \\
\hline Human & Tissue & Collagenase & Adipogenic & 79 \\
\hline Mice & $\begin{array}{l}\text { Inguinal, epidydimal, } \\
\text { and brown adipose tissue }\end{array}$ & Collagenase type II & Osteogenic & 80 \\
\hline Human & $\begin{array}{l}\text { Adipose synovium } \\
\text { and subcutaneus } \\
\text { adipose tissue }\end{array}$ & Collagenase D & $\begin{array}{l}\text { Chondrogenic, adipogenic, } \\
\text { and osteogenic }\end{array}$ & 81 \\
\hline Human & $\begin{array}{l}\text { Abdomen and hip } \\
\text { subcutaneus tissue }\end{array}$ & Collagenase & Adipogenic osteogenic & 82 \\
\hline Pig & Subcutaneus adipose tissue & Collagenase type I & Myogenic & 52 \\
\hline Piglet & Facial or abdominal fat & Collagenase type XI & $\begin{array}{l}\text { Adipogenic, chondrogenic, } \\
\text { osteogenic, and neurogenic }\end{array}$ & 53 \\
\hline Human & Lipoaspirated & Collagenase & Chondrogenic & 63 \\
\hline Human & Lipoaspirated & Collagenase & Cardiomyocytic lineage & 77 \\
\hline Mice & $\begin{array}{l}\text { White subcutaneus } \\
\text { adipose tissue from } \\
\text { inguinal region }\end{array}$ & Collagenase type I & Cardiomyocytic lineage & 78 \\
\hline Human & Lipoaspirated & Collagenase type I & $\begin{array}{l}\text { Chondrogenic, adipogenic, } \\
\text { and osteogenic }\end{array}$ & 87 \\
\hline Human & Lipoaspirated & Collagenase type I & $\begin{array}{l}\text { Adipogenic, chondrogenic, } \\
\text { and osteogenic }\end{array}$ & 88 \\
\hline Human & Subcutaneus liposuction & Collagenase type I & Chondrogenic & 89 \\
\hline Human & Subcutaneus liposuction & Collagenase type I & Osteogenic and lipogenic & 90 \\
\hline Mice & Lymph node adipose tissue & $\begin{array}{l}\text { Collagenase followed } \\
\text { by p75NTR-posive sorting }\end{array}$ & $\begin{array}{l}\text { Adipogenic, osteogenic, } \\
\text { chondrogenic, and } \\
\text { neurogenic smooth } \\
\text { muscle cells lineage }\end{array}$ & 92 \\
\hline Human & Subcutaneus liposuction & $\begin{array}{l}\text { Collagenase followed } \\
\text { by serial centrifugations }\end{array}$ & $\begin{array}{l}\text { Adipogenic, chondrogenic, } \\
\text { and cell lineage }\end{array}$ & 91 \\
\hline Human & Subcutaneus liposuction & $\begin{array}{l}\text { Collagenase followed } \\
\text { by serial centrifugations }\end{array}$ & Adipogenic and chondrogenic & 91 \\
\hline Human & Liposuction & $\begin{array}{l}\text { Collagenase followed } \\
\text { by immunomagnetic beads } \\
\text { cell purification for } \\
\text { CD34 } 4^{+} / \mathrm{CD} 31^{-}\end{array}$ & Lipogenic & 93 \\
\hline
\end{tabular}

the phenotypes that they can originate. ${ }^{17}$ In fact, the number of adult stem cells that can be found in the WAT is higher than that found in the brown adipose tissue, and the cells from WAT grow faster than the cells isolated from BAT. ${ }^{77}$ Further, there are significant differences in the surface markers found in stem cells obtained from white or brown adipose tissue, which suggests the possible existence of two different stem cell populations, corresponding to cells isolated from these two different types of fat tissue. ${ }^{17}$ The stem cells isolated from BAT and WAT differ also in their differentiation potential, as demonstrated by a study from Casteilla and coworkers, ${ }^{78}$ where it is shown that when the stem cells from these two different types of adipose tissue were cultured with osteogenic medium, the cells isolated from WAT exhibited a higher osteogenic differentiation potential.
In addition to the differences in the stem cells isolated from WAT or BAT that have been macroscopically detected, differences have also been found on ASCs isolated from subcutaneous WAT with respect to those isolated from visceral WAT and also when different subcutaneous depots were considered. ${ }^{46}$ Studies on ASCs isolated from visceral and subcutaneous adipose tissue shown that stem cells isolated from subcutaneous fat show a higher proliferation rate but a lower differentiation capacity, especially regarding the osteogenic differentiation as compared to the stem cells isolated from visceral fat tissue. ${ }^{46,77}$ An interesting study from Mochizuki et al. ${ }^{79}$ compares the chondrogenic differentiation potential of human ASCs isolated from fibrous synovium, adipose synovium, and subcutaneous fat, and, once again, it shows that there are significant differences between the cells 
isolated from the different sites. The cells isolated from fibrous synovium and fat synovium show the highest chondrogenic and osteogenic differentiation potentials and simultaneously the best results regarding the CFU-test than the human ASCs isolated from subcutaneous fat tissue.

There are differences in the ASC population even when the cells are isolated from the same type of adipose tissue but from two different anatomical regions, as demonstrated, for example, in a study by Wheeler and coworkers, ${ }^{80}$ which shows that the ASCs isolated from the subcutaneous fat tissue harvested from the hip have a higher osteogenic potential than ASCs harvested from the abdomen.

\section{Methods for the isolation of ASCs}

The first isolation method of cells from the adipose stromal vascular fraction (SVF) was optimized by the pioneer Rodbell in the far ' $60 \mathrm{~s} .{ }^{81-83}$ As mentioned before, Zuk and his collaborators were the first to report on the existence of ASCs in the fat tissue, in 2001. ${ }^{34}$ This group isolated the adult stem cells from fat tissue using an enzymatic method, which is still the basis of most methods used nowadays for this purpose, followed by a natural selection of the cells based on the propriety of ASCs to adhere to the plastic surface of tissue culture flasks. ${ }^{41,42,54,56,80,84-88}$ The enzyme used is most of the time collagenase type I varying in the concentration and in the incubation time (Table 1).

So far, only a very small number of alternative isolation/ purification methods are found in the literature. One of these alternative isolation procedures is described by Miyazaky et al., who uses serial centrifugation to collect two distinct phases and therefore isolated two different subpopulations, ${ }^{89}$ while Yamamoto et al. ${ }^{90}$ describes the use of cell sorting selecting the p75 receptor-positive cells, after the enzymatic isolation, and demonstrated the higher chondrogenic and osteogenic differentiation potential of the p75-positive cells than the p75-negative cells.

An elegant method to isolate $\mathrm{CD} 34^{+} / \mathrm{CD} 31^{-}$cells from SVF performing serial cell purification steps, using immunomagnetic beads, was developed by Sengenes et al., ${ }^{91}$ who demonstrated that the cell population isolated exhibited similar characteristics of adult mesenchymal stem cells. Also Rada et al. isolated human ASCs using immunomagnetic beads coated with several different antibodies (ab) markers for these cells, and compared the stemness and osteogenic and chondrogenic potential between the different subpopulations isolated and with the ASCs isolated with the enzymatic method. The results obtained in this study underline the complexity of the adipose tissue and ASCs where exist several stem cell subpopulations, each one with a proper marker expression and a proper differentiation potential. ${ }^{92}$

A study on the optimization of the classical isolation method was published recently ${ }^{50}$ with the aim of establishing the optimal centrifugation speed to isolate the highest number of ASCs and, at the same time, to exclude other cell types. The results obtained showed that the best centrifugation speed is $1200 \mathrm{~g}$, while when the gravity of the centrifugation reached $3000 \mathrm{~g}$, the ASCs are damaged.

Nevertheless, the examples reported above on alternative methods for ASC isolations are still few and limited in terms of the results produced. As described in the previous section, the adipose tissue is a complex tissue composed of several cell populations that adhere to the plastic surface of tissue culture flasks, such as erythrocyte, endothelial cells, adipocytes, neuron cells, adult stem cells, and fibroblasts. In addition, several studies show that fibroblasts inhibit the osteogenic differentiation ${ }^{46}$ and that these particular cells overgrow with respect to the remaining cell populations. For all these reasons and because of the presence of several ASC subpopulations in adipose tissue, it became obvious that further efforts should be directed to establish a clear and optimized isolation method that allows obtaining purified ASC populations with specific characteristics, by enabling the simultaneous isolation of these distinct ASC subpopulations that are present in the adipose tissue.

Another critical aspect regarding the isolation of the ASCs is related to the method used to harvest the adipose tissue. Considering the human model, the ASCs can be isolated from fat tissue wastes resulting from plastic/reconstructive surgeries, and minced into small fragments. When the starting point is the waste obtained from a liposuction procedure, the isolation method is simplified, as this procedure generates finely minced tissue fragments that have a more homogeneous and smaller volume than when a larger amount of tissue is minced manually, allowing a more efficient enzymatic digestion. ${ }^{3}$ A study by Fraser et al. ${ }^{80}$ has shown that the lipoaspiration surgery does not affect the ASCs, and apparently only the lipocytes are damaged, as these are cells of bigger dimensions that are affected by the mechanical stress applied during the liposuction.

\section{Characterization of the phenotype of ASCs}

Although several studies have been done to establish the markers of the ASC phenotype, this issue is still quite controversial. Table 2 summarizes the studies performed so far referring to different markers' expression of ASCs.

On the surface of ASCs, HLA-ABC, CD29, CD49e, CD51, and CD90 markers have been found with highly consistent patterns of expression. ${ }^{42}$ Other factors, such as CD49d, CD9, CD34, CD105, and CD166, are present in human ASC but with an expression level lower than $50 \%{ }^{41}$

The presence or absence of Stro- 1 is particularly controversial. In fact, there are studies that report the absence of this marker in ASC cultures, ${ }^{41}$ and others that relate its presence. ${ }^{35}$ The same happens regarding CD34 and CD106, because Gronthos et al. ${ }^{41}$ found these markers in ASCs, while Zuk et al. ${ }^{35}$ reports their absence, and for Katz et al. these markers are absent or expressed only on a negligible number of cells. ${ }^{42}$ These contradictory results may, however, be explained by the differences in marker antibodies sources and detection methods used in the referred studies. ${ }^{3}$

The expression of CD166, CD90, CD73, CD44, and CD29 changes during the cell passages ${ }^{88}$ : the expression level of these markers increases, considering the ASCs from the SVF from passage $0(\mathrm{p} 0)$, to passage $1(\mathrm{p} 1)$ and passage $2(\mathrm{p} 2)$, and becomes stable after passage $\mathrm{p} 2$.

The ASCs from human origin also express, in short-term cultures, molecules that are typical of the embryonic phenotype, such as OCT-4, UTF-1, and Nodal, ${ }^{93}$ which are crucial for the migration of embryonic precursors during development and that are necessary to maintain the undifferentiated status of embryonic stem cells in culture. ${ }^{93}$ In addition, analysis of the human ASC markers has shown the 
Table 2. Marker Expression/Phenotype of Adipose Stem Cells

\begin{tabular}{lcc}
\hline Cell type/cell origin & Cell markers present & Cell markers absent \\
\hline Human/liposuction & HLA-ABC; CD29; CD49e; CD51; & HLA-DR; CD8a; CD11a; CD18; \\
& CD90; CD49d; CD9; CD34; & CD41a; CD49f; CD62L; CD62P; \\
& CD105; CD166 & CD106; CD117; CD133; CD243; \\
Human/subcutaneus & ALA-ABC; CD9; CD10; CD13; & HLA-DR; CD11a; CD11b; CD11c; \\
& CD29; CD34; CD44; CD49e; & CD14; CD18; CD45; CD50; \\
& CD49d; CD54; CD55; CD59; & CD56; STRO-1 \\
Human/liposuction & CD105; CD146; CD166; CD106 & CD31; CD34; CD45; CD14; \\
& CD29; CD44; CD71; CD90; & CD16; CD56; CD61; CD62e; \\
Human & CD105/SH2; SH3; STRO-1; & CD104; CD106 \\
\hline
\end{tabular}

expression of Snail2 (Slug), a molecule that is associated with epithelial-mesenchymal transition in cancer metastasis.

This section clearly describes that the markers that have been reported in different studies on the characterization of ASCs are sometimes contradictory. In fact, several groups are currently studying ASCs, but the appropriate markers for the characterization of these cells are still far from being consensual.

\section{Differentiation potential of stem cells isolated from adipose tissue}

As it was mentioned in previous sections, the stem cells from adipose tissue have the ability to differentiate into several different cell types. It has been demonstrated that the ASCs have a neurogenic differentiation potential, ${ }^{34,74,94}$ cardiomyocyte and myocyte differentiation potential, ${ }^{72,75,76,95}$ endothelial cell differentiation potential, ${ }^{34,75}$ hepatocyte differentiation potential, ${ }^{96,97}$ adipogenic differentiation potential, $^{34,53,98}$ and of course osteogenic and chondrogenic differentiation potential. ${ }^{35,61,65,69,79}$ In this review the authors will focus particularly on the osteogenic and chondrogenic differentiation.

A large number of studies carried out so $\operatorname{far}^{3,5,16,34,35,53,63,65,99,100}$ indicate that ASCs undergo osteogenic differentiation within in 2-4 weeks of culture, when using the same culturing conditions used for the osteogenic differentiation of BMSCs. The mechanisms that drive the ASCs into the osteoblast lineage are still not clear. Nevertheless, some transcription factors such as PPAR $\gamma$ and Runx2 have been suggested to play a critical role in the commitment of bipotent stem cells with the capacity to differentiate to the osteoblastic or adipocyte phenotype. ${ }^{101}$ The role of the deltaFosB has also been investigated, and the results obtained ${ }^{102}$ showed that the overexpression of this transcription factor leads to an increased bone mass and decreased adipocyte formation.

As expected, the medium composition is very important in the induction of the osteogenic phenotype. Culture medium supplemented with dexamethasone and $\beta$-glycerolphosphate induces the osteogenic differentiation of ASCs. In fact, it has been demonstrated that ASCs cultured in the presence of these supplements express gene characteristics of osteoblastlike cells, such as Run-x, BMP-2, BMP4, BMP receptor I and II, and PTH receptor ${ }^{16,35,36}$; under these same culturing conditions, the ASCs are also able to form mineralized matrix. In other works, ${ }^{34,103} 1,25$-dihydroxyvitamin $\mathrm{D}_{3}$ (VD) has also been investigated as a differentiation factor. Apparently, VD inhibits adipogenesis and enhances osteogenesis in the $\mathrm{SAM} / \mathrm{P} 6$ mice, which is correlated to a $50 \%$ of reduction of PPAR $\gamma$ mRNA expression and protein synthesis, a decreasing of Oil Red positively stained cells and an induction of the osteoblastogenic genes. ${ }^{101,104,105}$

For inducing the osteogenic differentiation of ASCs, BMP-2 has also been used. In ASCs the presence of BMP-2 increases the expression of runx-2 and osteopontin, promoting the osteogenic differentiation. ${ }^{106}$ Another particularly important factor regarding the osteogenic differentiation of ASCs is the growth and differentiation factor 5 (GDF-5), which appears to be more effective than BMP-2 in the induction of the osteogenic differentiation, and it also increases the expression of vascular endothelial growth factor (VEGF), promoting the vascularization. ${ }^{107}$

As mentioned before, the ASCs can also differentiate into chondrocytes and used in potential tissue engineering-based approaches for the regeneration of cartilage defects. ASCs can express the biochemical markers associated to the chondrocyte phenotype, $5,87,108$ and when cultured with TGF$\beta$, ascorbate-2-phosphate, and dexamethasone, these cells secrete the extracellular matrix proteins, collagen II, collagen $\mathrm{IV}$, and aggrecan, typically found in native cartilage.

Bioactive factors of the BMP family have also been used for inducing the chondrogenic differentiation of ASCs. For example, it was found that BMP-6 promotes the chondrogenic differentiation while the BMP-7 induces the chondrogenic differentiation only when present in high doses. ${ }^{106,109}$ One other factor that seems to induce the chondrogenic differentiation is FGF-2, ${ }^{110}$ which is responsible for upregulating the expression of sox-9, a key factor in the chondrogenic differentiation.

A special mention has to be done regarding the ASCs' endothelial differentiation potential; in fact, the differentiation into this lineage is among the most recent findings regarding the research on the of ASCs' differentiation potential. ${ }^{111-113}$

Studies done on the cytokines expressed by ASC revealed a production of angiopoietin-1, and specially of hepatocyte growth factor and VEGF (the last two were at levels that were bioactive $)^{114,115}$; moreover, the presence of a stem cell population expressing $\mathrm{CD} 34^{116}$ in adipose tissue has been 
shown, and it has been shown that it is possible that this cell population can contribute to the formation of the vessels due to the potential for differentiating in endothelial cells.

Finally, Cao et al. ${ }^{112}$ published a study describing the isolation of $\mathrm{CD}^{-} 1^{-}, \mathrm{CD} 34^{-}, \mathrm{CD} 106^{-}$, and $\mathrm{FLK}^{+}$ASC subpopulations, which were able to express (in vitro) endothelial markers when cultured with VEGFs, such as CD31, CD34, CD144, and eNOS; the study also demonstrated that in vivo ASCs can differentiate into endothelial cells that contribute to neoangiogenesis in hind limb ischemia models.

\section{Immunological reactivity of ASCs}

The immunological behavior of ASCs has been described in a recent study, ${ }^{117}$ but many mechanisms and their detailed steps remain unclear. The ASCs were found to be negative regarding the expression of the most important immunologically relevant surface antigens, such as MHC-II, CD40, CD40L, CD80, and CD86, and these cells also do not express IL-10 and TGF- $\beta$, well-known inhibitor factors of lymphocytes $^{118}$; further, after the in vitro osteogenic differentiation of the ASCs, they remain negative for MHC-II, CD40, CD40L, CD80, and CD86 and thus for important T- and Bcell-costimulating surface antigen. ${ }^{117}$

Additionally, it was shown that the culture with allogenic lymphocytes did not lead to any enhancement of ASC proliferation, and when allogenical and activated lymphocytes are exposed to ASCs, the proliferation of the lymphocytes is inhibited. ${ }^{117}$ In summary, the ASCs are unable to incite a response of allogenic lymphocytes in vitro, inhibiting allogenic lymphocytes proliferation induced by allogenic PBMCs or mitogens. The inhibitory effect of the ASCs over lymphocytes proliferation was proportional to the number of stem cells and to the time of contact between stem cells and lymphocytes. ${ }^{118}$ However, despite the immunogenity properties described for ASCs, temporal changes have been described in vitro: in fact, when the cells are freshly isolated, they can elicit a T-cell proliferative response, decreasing the immunogenic response in the earlier passages (P0 and P1), which then disappears in later passages (P2-P4). ${ }^{119}$

\section{Mesenchymal stem cell sources: bone marrow versus adipose tissue}

The bone marrow has been the most widely used source of mesenchymal stem cells for tissue engineering and other cellbased therapies. ${ }^{16}$ Like the bone marrow, adipose tissue is also a mesodermally derived organ, and therefore it is quite obvious that stem cells derived from these two tissue share several characteristics, including the proliferative potential and the ability to undergo multilineage differentiation. ${ }^{16}$ The surface markers of these two stem cell populations are quite similar; in fact, both stem cell populations isolated from the bone marrow (BMSCs) and from the adipose tissue (ASCs) express CD105, STRO-1, and CD166, markers which are typically used to identify cells with multilineage differentiation potential. ASCs and BMSCs also express CD117, the stem cell factor receptor, and also CD29, CD44, and CD49e . $^{3,5,16,42}$ However, the two cell populations differ in the expression of CD54, for example, which has shown higher levels of expression in ASCs than BMSCs; in addition, CD49d is expressed only in the ASCs, while CD106 is expressed only by BMSCs. ${ }^{16}$
Studies on the immunological proprieties of ASCs and BMSCs $^{117,118}$ demonstrated that ASCs are immunoprivileged cells that may be therefore available for cell replacement therapies in HLA-incompatible hosts, before and after osteogenic differentiation in vitro since under both conditions, these cell showed no expression of important immunologically relevant surface antigen such as MHC-II, CD40, CD40L, and CD90.

ASCs and BMSCs can both differentiate into chondrocytes, osteoblasts, adipocytes, hepatocytes, neuron-like cells, and myocytes, but the differentiation potential is not always identical. It is still not clear which of the two stem cell populations has the highest chondrogenic differentiation potential, because despite the number of studies that have been carried on this subject, the results obtained are still controversial. Earlier studies ${ }^{35,85,108,120}$ show that there is no difference between ASCs and BMSCs regarding the chondrogenic differentiation potential, while some recent articles $^{121,122}$ claim that the BMSCs show an higher chondrogenic differentiation potential demonstrated by an higher expression of the genes correlated to the chondrogenic lineage and a higher synthesis of glycosaminoglycans (GAGs). However, the different results obtained might be explained by the different culturing conditions, as well as many other variability factors, such as the age of the donor. Finally, one should also consider that ASCs may need a different medium composition, that is, a different cocktail of growth factors to achieve a complete chondrogenic differentiation, because most studies performed with these cells are based on the same culturing conditions used for the stem cells obtained from the bone marrow.

In the same way, regarding the osteogenic differentiation, there are also controversial results with respect to the comparison between ASC and BMSC differentiation potential. ${ }^{5,35,85}$ Recently, an article was published ${ }^{100}$ where several differentiation pathways for ASCs and BMSCs were compared. In the early osteogenesis process of ASCs and BMSCs, even if osteomodulin (OMD) gene expression has been observed in both the cell populations, only in BMSCs was observed an increase of the expression during the differentiation and always associated with the expression of apolipoprotein-D (APOD). The two cell populations have shown also differences in other gene expression, always correlated with osteogenic differentiation such as TIMP4, RGC32, FOXO1A, and NR2F1, demonstrating that there are real differences between ASCs and BMSCs. ${ }^{100}$ Even if the cause of this difference in the gene expression could be imputed to the culture condition or growth factor cocktail, the ASCs could need different chemical stimuli considering the different niche of the two cell population. It is also important to highlight that none of these studies have considered the demonstrated possibility of ASCs obtained from different anatomical sites to have different responses to differentiation and, therefore, to the gene expression.

Finally, in a study by Kim et al., the neovascularization potential of BMSCs and ASCs was compared. This research group investigated the capacity to promote neovascularization in nude mice, showing that a better neovascularization was observed with ASCs, in both the cases, that is, when the neovascularization was induced by the transdifferentiation of the cells into endothelial cells and by the release of VEGF and bFGF. ${ }^{123}$ 
Table 3. Studies Regarding the Use of Adipose Stem Cells in Bone and Cartilage Tissue Engineering Applications Found in the Literature

\begin{tabular}{llr}
\hline Model & \multicolumn{1}{c}{ Application } & Reference \\
\hline Human ASCs in vitro & Bone tissue engineering & 66 \\
Human ASCs in nude rats & Bone tissue engineering \\
Human ASCs in vitro & Bone tissue engineering & 125 \\
Rat ASCs in vitro & Bone tissue engineering \\
Mouse ASCs in mice & Bone tissue engineering \\
Human ASCs in nude mice & Bone tissue engineering \\
Human ASCs in nude mice & Bone tissue engineering \\
Human ASCs in nude mice & Bone tissue engineering \\
Human ASCs in vitro & Cartilage tissue engineering \\
Rabbit ASCs in vitro & Cartilage tissue engineering \\
Human ASCs in nude mice & Cartilage tissue engineering \\
Human ASCs in nude mice & Cartilage tissue engineering \\
Human ASCs in vitro & Cartilage tissue engineering \\
Human ASCs in vitro & Cartilage tissue engineering & 126 \\
Rabbit ASCs in rabbit & Cartilage tissue engineering & 128 \\
\hline
\end{tabular}

ASC, adipose stem cells.

\section{Application of ASCs in Tissue Engineering Strategies}

\section{ASCs in bone tissue engineering}

Several studies have already been done in the field of bone tissue engineering using ASCs. ${ }^{64,124-126}$ In general, these studies have demonstrated that stem cells obtained from the adipose tissue exhibit good attachment properties to most of the material surfaces and the capacity to differentiate into osteoblastic- like cells in vitro and in vivo ${ }^{125,127}$ (Table 3).

Cowan et al. ${ }^{127}$ were the first to demonstrate that ASCs maintain their osteogenic differentiation capacity also in vivo. For that purpose, they used apatite-coated and noncoated poly(dl-lactide-co-glicolide) (PLGA) scaffolds, implanted in critical-size defects induced in mice for 12 weeks seeded and cultured with ASCs. The ASCs were isolated from FBV mice (a knockout mice), cultured until the confluence, and then the cells were seeded in the scaffolds that were implanted in a 4-mm-size defect, in the right parietal bone of adult FBV mice. The results obtained showed that the ASC-coated scaffold constructs were able to form new bone compared to the noncoated PLGA scaffolds, where less bone formation was found.

Peterson et al. ${ }^{124}$ have carried out a study using collagenceramic carriers and ASCs transfected with the BMP-2 gene implanted in nude mouse critical-size femoral defect. This study showed that the carrier was able to deliver the cells to the defect area and that, due to the effect of BMP-2, the ASCs were forming new bone, and thus the femoral defect was healed after 8 weeks of implantation.

In a study published in 2006, Hattori et al. ${ }^{128}$ compared the osteogenic differentiation potential between human BMSCs and ASCs using $\beta$-TCP scaffolds. The cell-scaffold constructs were cultured in vitro for 2 weeks with osteogenic medium and then implanted for 8 weeks in the back of nude mice. The results achieved in this study showed that there is no difference between BMSCs and ASCs regarding their osteogenic differentiation, and that the presence of either of these cells was also enhancing the vascularization process.

Shen et al. ${ }^{126}$ studied the osteogenic differentiation of rat ASCs seeded on a 3D scaffold obtained by sintering PLGA- based microspheres and cultured in the presence of GDF-5. The obtained results suggest that the cells treated with GDF-5 were not able to adhere to the scaffold, but remain viable and with the capacity to migrate, proliferate, and subsequently undergo osteogenic differentiation.

Another study by Kakudo et al. ${ }^{129}$ on the osteogenic differentiation of ASCs on collagen scaffolds with an honeycomb-like structure has shown that the ASCs differentiate into osteoblast-like cells and were able to produce matrix and to express the characteristic genes of osteoblasts.

Finally, recently it has been shown that ASCs may stimulate the vascularization process. In fact, Scherberich et al. ${ }^{130}$ demonstrated that ASCs cultured in vitro onto hydroxyapatite scaffolds in a 3D perfusion system with endothelial cells and also when transplanted into nude mice promote the formation of blood vessels. The induction of vascularization by the ASCs can be caused by the production of VEGF and other cytokine by the stem cells from adipose tissue. ${ }^{112,113,115}$

\section{Cartilage tissue engineering using ASCs}

Several studies have shown the potential of ASCs in several different cartilage tissue engineering approaches, demonstrating the chondrogenic differentiation potential when these cells are cultured using the typical aggregate culture technique (pellet culture) ${ }^{69}$ and when they are seeded in materials to be further cultured in vitro and/or implanted in different animal models ${ }^{131-133}$ (Table 3).

A work published in 2004 by Awad et al. ${ }^{66}$ describes one of the first studies on cartilage tissue engineering using stem cells isolated from human adipose tissue. This research group compared several different scaffolds based on agarose, alginate, and gelatine as support materials for hASC adhesion, proliferation, and chondrogenic differentiation. It was concluded that these cells were able to differentiate into chondrocyte when seeded/cultured into any of the studied scaffolds, although differences were found in the proliferation rate, indicating that the most appropriate scaffold material for the cell growth was the one based on gelatine. 
Betre et al. ${ }^{134}$ studied the ASCs' chondrogenic differentiation using elastin-like polypeptide as support matrices and demonstrated that the stem cells can grow and express the chondrogenic phenotype, namely, the expression of collagen II, aggrecan, and sox9 even when cultured without the supplemented media usually used to induce the chondrogenic differentiation.

Wei et al. ${ }^{131}$ tested the use of a injectable scaffold based on condroitin sulfate for the ASCs' condrogenic differentiation. The results showed good cell viability and growth and also that the ASCs differentiate into chondrocyte-like cells producing GAG.

Dragoo et al. ${ }^{135}$ studied the in vivo chondrogenic regeneration by implanting fibrin glue scaffolds seeded with ASCs in rabbits for 8 weeks. At the end of the implantation period, the ASCs were expressing aggrecan and collagen II, the cells were synthesizing GAGs, and new cartilage formation was observed.

\section{Present situation and future trends}

Since 2001, when the presence of stem cells in the adipose tissue was definitely demonstrated, many studies have been published on the subject, most of which concern the use of this alternative stem cell source in tissue engineering and/or regenerative medicine applications. Many studies have demonstrated the differentiation potential, as well as other necessary requirements that assign the designation of stem cells to this cell population.

The number of articles regarding the application of ASCs in the biomedical fields is impressive considering the youth of the ASCs' identification. However, by one side each article regarding the ASCs stimulates more research and knowledge development on ASCs, and by the other side this sort of marathon that aims to demonstrate the high potential of ASCs seems to be hazardous. In fact, too many pieces of this puzzle are still hidden, concerning not only the fundamental and basic mechanisms behind ASC biology, but also some practical issues, such as the most appropriate isolation procedure or the location of the tissue of origin. The expression of several markers is still on discussion, the pathways and mechanisms that avoid an immunoresponse related to ASCs are still unknown, and no long-term in vivo experiment has been done until now to demonstrate the in vivo functionality of these cells. Therefore, exploring the applications of ASCs without having a profound knowledge of the tool has become almost an impossible mission. Further, recent articles ${ }^{136-138}$ show that the ASCs cultured in vitro under normal culture conditions for an extended period of time can transform into cancer cells, like it has been reported for embryonic stem cell cultures. Considering that ASCs express genes typical of the embryonic stem cells, ${ }^{93}$ it is reasonable to suppose that ASCs have several common characteristics of the embryonic stem cells, including a mutagenic activity.

Finally, the discrepancy in the studies concerning the expression of some markers may be related to the different culturing conditions, but it can also mean that the stem cells from adipose tissue constitute a complex population consisting in several cell subpopulations each one with specific characteristics and potential; in fact, the presence of several subpopulations is not a new discovery because in BMSCs the isolation/purification of subpopulation with different differentiation potential is well documented. ${ }^{139-141}$ However, regarding ASCs, there are only a few articles that analyze this hypothesis. ${ }^{91,113,116}$

Although the studies based on tissue engineering and regenerative medicine therapies focused on the ASCs raise a great hope to all the researchers working in this field, it is important to realize that in the near future, more studies and efforts to understand the biology of the ASCs are mandatory, as only better and profound knowledge of these cells will enable to develop useful, safe, and powerful applications of ASCs in the biomedical field.

\section{Acknowledgments}

T. Rada thanks the European Marie Curie EST Project (Alea Jacta Est) for the Ph.D. fellowship. The authors acknowledge the Portuguese Foundation for Science and Technology (FCT) for the partial financial support through funds from POCTI and/or FEDER programs and to the European Union funded STREP Project HIPPOCRATES (NMP3-CT-2003-505758) and the European NoE EXPERTISSUES (NMP3-CT-2004-500283).

\section{Disclosure Statement}

All the authors declare that no competing financial interests exist.

\section{References}

1. Langer, R., and Vacanti, J.P. Tissue engineering. Science 260, 920, 1993.

2. Gomes, M.E., and Reis, R.L. Tissue engineering: key elements and some trends. Macromol Biosci 4, 737, 2004.

3. Gimble, J.M., Katz, A.J., and Bunnell, B.A. Adipose-derived stem cells for regenerative medicine. Circ Res 100, 1249, 2007.

4. Rodriguez, A.M., Elabd, C., Amri, E.Z., Ailhaud, G., and Dani, C. The human adipose tissue is a source of multipotent stem cells. Biochimie 87, 125, 2005.

5. Gimble, J., and Guilak, F. Adipose-derived adult stem cells: isolation, characterization, and differentiation potential. Cytotherapy 5, 362, 2003.

6. Bunnell, B.A., Flaat, M., Gagliardi, C., Patel, B., and Ripoll, C. Adipose-derived stem cells: isolation, expansion and differentiation. Methods 45, 115, 2008.

7. Bianco, P., and Robey, P.G. Stem cells in tissue engineering. Nature 414, 118, 2001.

8. Bianco, P., Riminucci, M., Gronthos, S., and Robey, P.G. Bone marrow stromal stem cells: nature, biology, and potential applications. Stem Cells 19, 180, 2001.

9. Weissman, I.L., Anderson, D.J., and Gage, F. Stem and progenitor cells: origins, phenotypes, lineage commitments, and transdifferentiations. Annu Rev Cell Dev Biol 17, 387, 2001.

10. Adachi, N., Sato, K., Usas, A., Fu, F.H., Ochi, M., Han, C.W., Niyibizi, C., and Huard, J. Muscle derived, cell based ex vivo gene therapy for treatment of full thickness articular cartilage defects. J Rheumatol 29, 1920, 2002.

11. Doherty, M.J., Ashton, B.A., Walsh, S., Beresford, J.N., Grant, M.E., and Canfield, A.E. Vascular pericytes express 
osteogenic potential in vitro and in vivo. J Bone Miner Res 13, 828, 1998.

12. Vandenabeele, F., De Bari, C., Moreels, M., Lambrichts, I., Dell'Accio, F., Lippens, P.L., and Luyten, F.P. Morphological and immunocytochemical characterization of cultured fibroblast-like cells derived from adult human synovial membrane. Arch Histol Cytol 66, 145, 2003.

13. Young, H.E., Steele, T.A., Bray, R.A., Detmer, K., Blake, L.W., Lucas, P.W., and Black, A.C., Jr. Human pluripotent and progenitor cells display cell surface cluster differentiation markers CD10, CD13, CD56, and MHC class-I. Proc Soc Exp Biol Med 221, 63, 1999.

14. Young, H.E., Steele, T.A., Bray, R.A., Hudson, J., Floyd, J.A., Hawkins, K., Thomas, K., Austin, T., Edwards, C., Cuzzourt, J., Duenzl, M., Lucas, P.A., and Black, A.C., Jr. Human reserve pluripotent mesenchymal stem cells are present in the connective tissues of skeletal muscle and dermis derived from fetal, adult, and geriatric donors. Anat Rec 264, 51, 2001.

15. Gimble, J.M., and Guilak, F. Differentiation potential of adipose derived adult stem (ADAS) cells. Curr Top Dev Biol 58, 137, 2003.

16. Strem, B.M., Hicok, K.C., Zhu, M., Wulur, I., Alfonso, Z., Schreiber, R.E., Fraser, J.K., and Hedrick, M.H. Multipotential differentiation of adipose tissue-derived stem cells. Keio J Med 54, 132, 2005.

17. Avram, A.S., Avram, M.M., and James, W.D. Subcutaneous fat in normal and diseased states: 2. Anatomy and physiology of white and brown adipose tissue. J Am Acad Dermatol 53, 671, 2005.

18. Cinti, S. Adipocyte differentiation and transdifferentiation: plasticity of the adipose organ. J Endocrinol Invest 25, 823, 2002.

19. Lean, M.E. Brown adipose tissue in humans. Proc Nutr Soc 48, 243, 1989.

20. Raboi, C.A., and Smith, W. Brown fat necrosis in the setting of congenital heart disease and prostaglandin E1 use: a case report. Pediatr Radiol 29, 61, 1999.

21. Fukuchi, K., Ono, Y., Nakahata, Y., Okada, Y., Hayashida, K., and Ishida, Y. Visualization of interscapular brown adipose tissue using $(99 \mathrm{~m})$ Tc-tetrofosmin in pediatric patients. J Nucl Med 44, 1582, 2003.

22. Himms-Hagen, J. Does brown adipose tissue (BAT) have a role in the physiology or treatment of human obesity? Rev Endocr Metab Disord 2, 395, 2001.

23. Penicaud, L., Cousin, B., Leloup, C., Lorsignol, A., and Casteilla, L. The autonomic nervous system, adipose tissue plasticity, and energy balance. Nutrition 16, 903, 2000.

24. Poissonnet, C.M., LaVelle, M., and Burdi, A.R. Growth and development of adipose tissue. J Pediatr 113, 1, 1988.

25. Burdi, A.R., Poissonnet, C.M., Garn, S.M., Lavelle, M., Sabet, M.D., and Bridges, P. Adipose tissue growth patterns during human gestation: a histometric comparison of buccal and gluteal fat depots. Int J Obes 9, 247, 1985.

26. Smith, S.R., Lovejoy, J.C., Greenway, F., Ryan, D., deJonge, L., de la Bretonne, J., Volafova, J., and Bray, G.A. Contributions of total body fat, abdominal subcutaneous adipose tissue compartments, and visceral adipose tissue to the metabolic complications of obesity. Metabolism 50, 425, 2001.

27. Abate, N., Burns, D., Peshock, R.M., Garg, A., and Grundy, S.M. Estimation of adipose tissue mass by magnetic resonance imaging: validation against dissection in human cadavers. J Lipid Res 35, 1490, 1994.
28. Abate, N., Garg, A., Peshock, R.M., Stray-Gundersen, J., and Grundy, S.M. Relationships of generalized and regional adiposity to insulin sensitivity in men. J Clin Invest 96, 88, 1995.

29. Marin, P., Andersson, B., Ottosson, M., Olbe, L., Chowdhury, B., Kvist, H., Holm, G., Sjostrom, L., and Bjorntorp, P. The morphology and metabolism of intraabdominal adipose tissue in men. Metabolism 41, 1242, 1992.

30. Zhang, Y., Proenca, R., Maffei, M., Barone, M., Leopold, L., and Friedman, J.M. Positional cloning of the mouse obese gene and its human homologue. Nature 372, 425, 1994.

31. Cianflone, K., Xia, Z., and Chen, L.Y. Critical review of acylation-stimulating protein physiology in humans and rodents. Biochim Biophys Acta 1609, 127, 2003.

32. Arita, Y., Kihara, S., Ouchi, N., Takahashi, M., Maeda, K., Miyagawa, J., Hotta, K., Shimomura, I., Nakamura, T., Miyaoka, K., Kuriyama, H., Nishida, M., Yamashita, S., Okubo, K., Matsubara, K., Muraguchi, M., Ohmoto, Y., Funahashi, T., and Matsuzawa, Y. Paradoxical decrease of an adipose-specific protein, adiponectin, in obesity. Biochem Biophys Res Commun 257, 79, 1999.

33. Sethi, J.K., and Hotamisligil, G.S. The role of TNF alpha in adipocyte metabolism. Semin Cell Dev Biol 10, 19, 1999.

34. Zuk, P.A., Zhu, M., Mizuno, H., Huang, J., Futrell, J.W., Katz, A.J., Benhaim, P., Lorenz, H.P., and Hedrick, M.H. Multilineage cells from human adipose tissue: implications for cell-based therapies. Tissue Eng 7, 211, 2001.

35. Zuk, P.A., Zhu, M., Ashjian, P., De Ugarte, D.A., Huang, J.I., Mizuno, H., Alfonso, Z.C., Fraser, J.K., Benhaim, P., and Hedrick, M.H. Human adipose tissue is a source of multipotent stem cells. Mol Biol Cell 13, 4279, 2002.

36. Halvorsen, Y.D., Franklin, D., Bond, A.L., Hitt, D.C., Auchter, C., Boskey, A.L., Paschalis, E.P., Wilkison, W.O., and Gimble, J.M. Extracellular matrix mineralization and osteoblast gene expression by human adipose tissuederived stromal cells. Tissue Eng 7, 729, 2001.

37. Gimble, J.M., and Nuttall, M.E. Bone and fat: old questions, new insights. Endocrine 23, 183, 2004.

38. Nuttall, M.E., and Gimble, J.M. Controlling the balance between osteoblastogenesis and adipogenesis and the consequent therapeutic implications. Curr Opin Pharmacol 4, 290, 2004

39. Chamberlain, G., Fox, J., Ashton, B., and Middleton, J. Mesenchymal stem cells: their phenotype, differentiation capacity, immunological features and potential for homing. Stem Cells 25, 2739, 2007.

40. Festy, F., Hoareau, L., Bes-Houtmann, S., Pequin, A.M., Gonthier, M.P., Munstun, A., Hoarau, J.J., Cesari, M., and Roche, R. Surface protein expression between human adipose tissue-derived stromal cells and mature adipocytes. Histochem Cell Biol 124, 113, 2005.

41. Gronthos, S., Franklin, D.M., Leddy, H.A., Robey, P.G., Storms, R.W., and Gimble, J.M. Surface protein characterization of human adipose tissue-derived stromal cells. J Cell Physiol 189, 54, 2001.

42. Katz, A.J., Tholpady, A., Tholpady, S.S., Shang, H., and Ogle, R.C. Cell surface and transcriptional characterization of human adipose-derived adherent stromal (hADAS) cells. Stem Cells 23, 412, 2005.

43. Kern, S., Eichler, H., Stoeve, J., Kluter, H., and Bieback, K. Comparative analysis of mesenchymal stem cells from bone marrow, umbilical cord blood, or adipose tissue. Stem Cells 24, 1294, 2006. 
44. Wagner, W., Wein, F., Seckinger, A., Frankhauser, M., Wirkner, U., Krause, U., Blake, J., Schwager, C., Eckstein, V., Ansorge, W., and Ho, A.D. Comparative characteristics of mesenchymal stem cells from human bone marrow, adipose tissue, and umbilical cord blood. Exp Hematol 33, 1402, 2005.

45. Torres, F.C., Rodrigues, C.J., Stocchero, I.N., and Ferreira, M.C. Stem cells from the fat tissue of rabbits: an easy-tofind experimental source. Aesthetic Plast Surg 31, 574, 2007.

46. Peptan, I.A., Hong, L., and Mao, J.J. Comparison of osteogenic potentials of visceral and subcutaneous adiposederived cells of rabbits. Plast Reconstr Surg 117, 1462, 2006.

47. Black, L.L., Gaynor, J., Gahring, D., Adams, C., Aron, D., Harman, S., Gingerich, D.A., and Harman, R. Effect of adipose-derived mesenchymal stem and regenerative cells on lameness in dogs with chronic osteoarthritis of the coxofemoral joints: a randomized, double-blinded, multicenter, controlled trial. Vet Ther 8, 272, 2007.

48. Cui, L., Liu, B., Liu, G., Zhang, W., Cen, L., Sun, J., Yin, S., Liu, W., and Cao, Y. Repair of cranial bone defects with adipose derived stem cells and coral scaffold in a canine model. Biomaterials 28, 5477, 2007.

49. Li, H., Dai, K., Tang, T., Zhang, X., Yan, M., and Lou, J. Bone regeneration by implantation of adipose-derived stromal cells expressing BMP-2. Biochem Biophys Res Commun 356, 836, 2007.

50. Kurita, M., Matsumoto, D., Shigeura, T., Sato, K., Gonda, K., Harii, K., and Yoshimura, K. Influences of centrifugation on cells and tissues in liposuction aspirates: optimized centrifugation for lipotransfer and cell isolation. Plast Reconstr Surg 121, 1033; discussion 42, 2008.

51. Fotuhi, P., Song, Y.H., and Alt, E. Electrophysiological consequence of adipose-derived stem cell transplantation in infarcted porcine myocardium. Europace 9, 1218, 2007.

52. Huang, T., He, D., Kleiner, G., and Kuluz, J. Neuron-like differentiation of adipose-derived stem cells from infant piglets in vitro. J Spinal Cord Med 30 Suppl 1, S35, 2007.

53. Qu, C.Q., Zhang, G.H., Zhang, L.J., and Yang, G.S. Osteogenic and adipogenic potential of porcine adipose mesenchymal stem cells. In Vitro Cell Dev Biol Anim 43, 95, 2007.

54. Dubois, S.G., Floyd, E.Z., Zvonic, S., Kilroy, G., Wu, X., Carling, S., Halvorsen, Y.D., Ravussin, E., and Gimble, J.M. Isolation of human adipose-derived stem cells from biopsies and liposuction specimens. Methods Mol Biol 449, 69, 2008.

55. Fraser, J.K., Zhu, M., Wulur, I., and Alfonso, Z. Adiposederived stem cells. Methods Mol Biol 449, 59, 2008.

56. Hattori, H., Sato, M., Masuoka, K., Ishihara, M., Kikuchi, T., Matsui, T., Takase, B., Ishizuka, T., Kikuchi, M., Fujikawa, $\mathrm{K}$. , and Ishihara, M. Osteogenic potential of human adipose tissue-derived stromal cells as an alternative stem cell source. Cells Tissues Organs 178, 2, 2004.

57. Hicok, K.C., Du Laney, T.V., Zhou, Y.S., Halvorsen, Y.D., Hitt, D.C., Cooper, L.F., and Gimble, J.M. Human adiposederived adult stem cells produce osteoid in vivo. Tissue Eng 10, 371, 2004.

58. Khlusov, I.A., Karlov, A.V., Sharkeev, Y.P., Pichugin, V.F., Kolobov, Y.P., Shashkina, G.A., Ivanov, M.B., Legostaeva, E.V., and Sukhikh, G.T. Osteogenic potential of mesenchymal stem cells from bone marrow in situ: role of physicochemical properties of artificial surfaces. Bull Exp Biol Med 140, 144, 2005.
59. Knippenberg, M., Helder, M.N., Doulabi, B.Z., Semeins, C.M., Wuisman, P.I., and Klein-Nulend, J. Adipose tissuederived mesenchymal stem cells acquire bone cell-like responsiveness to fluid shear stress on osteogenic stimulation. Tissue Eng 11, 1780, 2005.

60. Ogawa, R., Mizuno, H., Hyakusoku, H., and Shimada, T. Bone marrow regeneration using adipose-derived stem cells. J Nippon Med Sch 73, 45, 2006.

61. Ogawa, R., Mizuno, H., Watanabe, A., Migita, M., Shima$\mathrm{da}, \mathrm{T}$., and Hyakusoku, H. Osteogenic and chondrogenic differentiation by adipose-derived stem cells harvested from GFP transgenic mice. Biochem Biophys Res Commun 313, 871, 2004.

62. Romanov, Y.A., Darevskaya, A.N., Merzlikina, N.V., and Buravkova, L.B. Mesenchymal stem cells from human bone marrow and adipose tissue: isolation, characterization, and differentiation potentialities. Bull Exp Biol Med 140, 138, 2005.

63. Shi, Y.Y., Nacamuli, R.P., Salim, A., and Longaker, M.T. The osteogenic potential of adipose-derived mesenchymal cells is maintained with aging. Plast Reconstr Surg 116, 1686, 2005.

64. Weinzierl, K., Hemprich, A., and Frerich, B. Bone engineering with adipose tissue derived stromal cells. J Craniomaxillofac Surg 34, 466, 2006.

65. Xu, Y., Malladi, P., Wagner, D.R., and Longaker, M.T. Adipose-derived mesenchymal cells as a potential cell source for skeletal regeneration. Curr Opin Mol Ther 7, 300, 2005.

66. Awad, H.A., Wickham, M.Q., Leddy, H.A., Gimble, J.M., and Guilak, F. Chondrogenic differentiation of adiposederived adult stem cells in agarose, alginate, and gelatin scaffolds. Biomaterials 25, 3211, 2004.

67. Guilak, F., Awad, H.A., Fermor, B., Leddy, H.A., and Gimble, J.M. Adipose-derived adult stem cells for cartilage tissue engineering. Biorheology 41, 389, 2004.

68. Huang, J.I., Beanes, S.R., Zhu, M., Lorenz, H.P., Hedrick, M.H., and Benhaim, P. Rat extramedullary adipose tissue as a source of osteochondrogenic progenitor cells. Plast Reconstr Surg 109, 1033; discussion 42, 2002.

69. Huang, J.I., Kazmi, N., Durbhakula, M.M., Hering, T.M., Yoo, J.U., and Johnstone, B. Chondrogenic potential of progenitor cells derived from human bone marrow and adipose tissue: a patient-matched comparison. J Orthop Res 23, 1383, 2005.

70. Huang, J.I., Zuk, P.A., Jones, N.F., Zhu, M., Lorenz, H.P., Hedrick, M.H., and Benhaim, P. Chondrogenic potential of multipotential cells from human adipose tissue. Plast Reconstr Surg 113, 585, 2004.

71. Di Rocco, G., Iachininoto, M.G., Tritarelli, A., Straino, S., Zacheo, A., Germani, A., Crea, F., and Capogrossi, M.C. Myogenic potential of adipose-tissue-derived cells. J Cell Sci 119, 2945, 2006.

72. Lee, J.H., and Kemp, D.M. Human adipose-derived stem cells display myogenic potential and perturbed function in hypoxic conditions. Biochem Biophys Res Commun 341, 882, 2006.

73. Kang, S.K., Putnam, L.A., Ylostalo, J., Popescu, I.R., Dufour, J., Belousov, A., and Bunnell, B.A. Neurogenesis of Rhesus adipose stromal cells. J Cell Sci 117, 4289, 2004.

74. Safford, K.M., Hicok, K.C., Safford, S.D., Halvorsen, Y.D., Wilkison, W.O., Gimble, J.M., and Rice, H.E. Neurogenic differentiation of murine and human adipose-derived stromal cells. Biochem Biophys Res Commun 294, 371, 2002. 
75. Fraser, J.K., Schreiber, R., Strem, B., Zhu, M., Alfonso, Z., Wulur, I., and Hedrick, M.H. Plasticity of human adipose stem cells toward endothelial cells and cardiomyocytes. Nat Clin Pract Cardiovasc Med 3 Suppl 1, S33, 2006.

76. Strem, B.M., Zhu, M., Alfonso, Z., Daniels, E.J., Schreiber, R., Beygui, R., MacLellan, W.R., Hedrick, M.H., and Fraser, J.K. Expression of cardiomyocytic markers on adipose tissue-derived cells in a murine model of acute myocardial injury. Cytotherapy 7, 282, 2005.

77. Tchkonia, T., Giorgadze, N., Pirtskhalava, T., Thomou, T., DePonte, M., Koo, A., Forse, R.A., Chinnappan, D., MartinRuiz, C., von Zglinicki, T., and Kirkland, J.L. Fat depotspecific characteristics are retained in strains derived from single human preadipocytes. Diabetes 55, 2571, 2006.

78. Prunet-Marcassus, B., Cousin, B., Caton, D., Andre, M., Penicaud, L., and Casteilla, L. From heterogeneity to plasticity in adipose tissues: site-specific differences. Exp Cell Res 312, 727, 2006.

79. Mochizuki, T., Muneta, T., Sakaguchi, Y., Nimura, A., Yokoyama, A., Koga, H., and Sekiya, I. Higher chondrogenic potential of fibrous synovium- and adipose synoviumderived cells compared with subcutaneous fat-derived cells: distinguishing properties of mesenchymal stem cells in humans. Arthritis Rheum 54, 843, 2006.

80. Fraser, J.K., Wulur, I., Alfonso, Z., Zhu, M., and Wheeler, E.S. Differences in stem and progenitor cell yield in different subcutaneous adipose tissue depots. Cytotherapy $\mathbf{9}$, 459, 2007.

81. Rodbell, M. Metabolism of isolated fat cells. I. Effects of hormones on glucose metabolism and lipolysis. J Biol Chem 239, 375, 1964.

82. Rodbell, M. The metabolism of isolated fat cells. IV. Regulation of release of protein by lipolytic hormones and insulin. J Biol Chem 241, 3909, 1966.

83. Rodbell, M. Metabolism of isolated fat cells. II. The similar effects of phospholipase C (Clostridium perfringens alpha toxin) and of insulin on glucose and amino acid metabolism. J Biol Chem 241, 130, 1966.

84. Boquest, A.C., Shahdadfar, A., Brinchmann, J.E., and Collas, P. Isolation of stromal stem cells from human adipose tissue. Methods Mol Biol 325, 35, 2006.

85. De Ugarte, D.A., Morizono, K., Elbarbary, A., Alfonso, Z., Zuk, P.A., Zhu, M., Dragoo, J.L., Ashjian, P., Thomas, B., Benhaim, P., Chen, I., Fraser, J., and Hedrick, M.H. Comparison of multi-lineage cells from human adipose tissue and bone marrow. Cells Tissues Organs 174, 101, 2003.

86. Dicker, A., Le Blanc, K., Astrom, G., van Harmelen, V., Gotherstrom, C., Blomqvist, L., Arner, P., and Ryden, M. Functional studies of mesenchymal stem cells derived from adult human adipose tissue. Exp Cell Res 308, 283, 2005.

87. Erickson, G.R., Gimble, J.M., Franklin, D.M., Rice, H.E., Awad, H., and Guilak, F. Chondrogenic potential of adipose tissue-derived stromal cells in vitro and in vivo. Biochem Biophys Res Commun 290, 763, 2002.

88. Mitchell, J.B., McIntosh, K., Zvonic, S., Garrett, S., Floyd, Z.E., Kloster, A., Di Halvorsen, Y., Storms, R.W., Goh, B., Kilroy, G., Wu, X., and Gimble, J.M. Immunophenotype of human adipose-derived cells: temporal changes in stromalassociated and stem cell-associated markers. Stem Cells 24, 376, 2006.

89. Miyazaki, T., Kitagawa, Y., Toriyama, K., Kobori, M., and Torii, S. Isolation of two human fibroblastic cell populations with multiple but distinct potential of mesenchymal differentiation by ceiling culture of mature fat cells from subcutaneous adipose tissue. Differentiation 73, 69, 2005.

90. Yamamoto, N., Akamatsu, H., Hasegawa, S., Yamada, T., Nakata, S., Ohkuma, M., Miyachi, E., Marunouchi, T., and Matsunaga, K. Isolation of multipotent stem cells from mouse adipose tissue. J Dermatol Sci 48, 43, 2007.

91. Sengenes, C., Lolmede, K., Zakaroff-Girard, A., Busse, R., and Bouloumie, A. Preadipocytes in the human subcutaneous adipose tissue display distinct features from the adult mesenchymal and hematopoietic stem cells. J Cell Physiol 205, 114, 2005.

92. Rada, T., Gomes, M.E., Neves, N.M., and Reis, R.L. Isolation of adipose stem cells (ASCs) subpopulations with distinct differentiation potential. Tissue Eng Part A 14, OP173, 2008.

93. Peroni, D., Scambi, I., Pasini, A., Lisi, V., Bifari, F., Krampera, M., Rigotti, G., Sbarbati, A., and Galie, M. Stem molecular signature of adipose-derived stromal cells. Exp Cell Res 314, 603, 2008.

94. Fujimura, J., Ogawa, R., Mizuno, H., Fukunaga, Y., and Suzuki, H. Neural differentiation of adipose-derived stem cells isolated from GFP transgenic mice. Biochem Biophys Res Commun 333, 116, 2005.

95. Planat-Benard, V., Menard, C., Andre, M., Puceat, M., Perez, A., Garcia-Verdugo, J.M., Penicaud, L., and Casteilla, L. Spontaneous cardiomyocyte differentiation from adipose tissue stroma cells. Circ Res 94, 223, 2004.

96. Yamamoto, Y., Banas, A., Murata, S., Ishikawa, M., Lim, C.R., Teratani, T., Hatada, I., Matsubara, K., Kato, T., and Ochiya, T. A comparative analysis of the transcriptome and signal pathways in hepatic differentiation of human adipose mesenchymal stem cells. Febs J 275, 1260, 2008.

97. Stock, P., Staege, M.S., Muller, L.P., Sgodda, M., Volker, A., Volkmer, I., Lutzkendorf, J., and Christ, B. Hepatocytes derived from adult stem cells. Transplant Proc 40, 620, 2008.

98. Ogawa, R., Mizuno, H., Watanabe, A., Migita, M., Hyakusoku, H., and Shimada, T. Adipogenic differentiation by adipose-derived stem cells harvested from GFP transgenic mice-including relationship of sex differences. Biochem Biophys Res Commun 319, 511, 2004.

99. Im, G.I., Shin, Y.W., and Lee, K.B. Do adipose tissuederived mesenchymal stem cells have the same osteogenic and chondrogenic potential as bone marrow-derived cells? Osteoarthritis Cartilage 13, 845, 2005.

100. Liu, T.M., Martina, M., Hutmacher, D.W., Hui, J.H., Lee, E.H., and Lim, B. Identification of common pathways mediating differentiation of bone marrow- and adipose tissue-derived human mesenchymal stem cells into three mesenchymal lineages. Stem Cells 25, 750, 2007.

101. Gimble, J.M., Zvonic, S., Floyd, Z.E., Kassem, M., and Nuttall, M.E. Playing with bone and fat. J Cell Biochem 98, 251, 2006.

102. Sabatakos, G., Sims, N.A., Chen, J., Aoki, K., Kelz, M.B., Amling, M., Bouali, Y., Mukhopadhyay, K., Ford, K., Nestler, E.J., and Baron, R. Overexpression of DeltaFosB transcription factor(s) increases bone formation and inhibits adipogenesis. Nat Med 6, 985, 2000.

103. Gupta, A., Leong, D.T., Bai, H.F., Singh, S.B., Lim, T.C., and Hutmacher, D.W. Osteo-maturation of adipose-derived stem cells required the combined action of vitamin D3, beta-glycerophosphate, and ascorbic acid. Biochem Biophys Res Commun 362, 17, 2007.

104. Duque, G., Macoritto, M., Dion, N., Ste-Marie, L.G., and Kremer, R. 1,25(OH)2D3 acts as a bone-forming agent in the 
hormone-independent senescence-accelerated mouse (SAMP/6). Am J Physiol Endocrinol Metab 288, E723, 2005.

105. Duque, G., Macoritto, M., and Kremer, R. Vitamin D treatment of senescence accelerated mice (SAM-P/6) induces several regulators of stromal cell plasticity. Biogerontology 5, 421, 2004.

106. Knippenberg, M., Helder, M.N., Zandieh Doulabi, B., Wuisman, P.I., and Klein-Nulend, J. Osteogenesis versus chondrogenesis by BMP-2 and BMP-7 in adipose stem cells. Biochem Biophys Res Commun 342, 902, 2006.

107. Zeng, Q., Li, X., Beck, G., Balian, G., and Shen, F.H. Growth and differentiation factor-5 (GDF-5) stimulates osteogenic differentiation and increases vascular endothelial growth factor (VEGF) levels in fat-derived stromal cells in vitro. Bone 40, 374, 2007.

108. Winter, A., Breit, S., Parsch, D., Benz, K., Steck, E., Hauner, H., Weber, R.M., Ewerbeck, V., and Richter, W. Cartilagelike gene expression in differentiated human stem cell spheroids: a comparison of bone marrow-derived and adipose tissue-derived stromal cells. Arthritis Rheum 48, 418, 2003.

109. Estes, B.T., Wu, A.W., and Guilak, F. Potent induction of chondrocytic differentiation of human adipose-derived adult stem cells by bone morphogenetic protein 6 . Arthritis Rheum 54, 1222, 2006.

110. Chiou, M., Xu, Y., and Longaker, M.T. Mitogenic and chondrogenic effects of fibroblast growth factor-2 in adipose-derived mesenchymal cells. Biochem Biophys Res Commun 343, 644, 2006.

111. Zannettino, A.C., Paton, S., Arthur, A., Khor, F., Itescu, S., Gimble, J.M., and Gronthos, S. Multipotential human adipose-derived stromal stem cells exhibit a perivascular phenotype in vitro and in vivo. J Cell Physiol 214, 413, 2008.

112. Cao, Y., Sun, Z., Liao, L., Meng, Y., Han, Q., and Zhao, R.C. Human adipose tissue-derived stem cells differentiate into endothelial cells in vitro and improve postnatal neovascularization in vivo. Biochem Biophys Res Commun 332, 370, 2005.

113. Nakagami, H., Morishita, R., Maeda, K., Kikuchi, Y., Ogihara, T., and Kaneda, Y. Adipose tissue-derived stromal cells as a novel option for regenerative cell therapy. J Atheroscler Thromb 13, 77, 2006.

114. Rehman, J., Considine, R.V., Bovenkerk, J.E., Li, J., Slavens, C.A., Jones, R.M., and March, K.L. Obesity is associated with increased levels of circulating hepatocyte growth factor. J Am Coll Cardiol 41, 1408, 2003.

115. Rehman, J., Traktuev, D., Li, J., Merfeld-Clauss, S., TemmGrove, C.J., Bovenkerk, J.E., Pell, C.L., Johnstone, B.H., Considine, R.V., and March, K.L. Secretion of angiogenic and antiapoptotic factors by human adipose stromal cells. Circulation 109, 1292, 2004.

116. Miranville, A., Heeschen, C., Sengenes, C., Curat, C.A., Busse, R., and Bouloumie, A. Improvement of postnatal neovascularization by human adipose tissue-derived stem cells. Circulation 110, 349, 2004.

117. Niemeyer, P., Kornacker, M., Mehlhorn, A., Seckinger, A., Vohrer, J., Schmal, H., Kasten, P., Eckstein, V., Sudkamp, N.P., and Krause, U. Comparison of immunological properties of bone marrow stromal cells and adipose tissuederived stem cells before and after osteogenic differentiation in vitro. Tissue Eng 13, 111, 2007.

118. Puissant, B., Barreau, C., Bourin, P., Clavel, C., Corre, J., Bousquet, C., Taureau, C., Cousin, B., Abbal, M., Laharrague, P., Penicaud, L., Casteilla, L., and Blancher, A. Immunomodulatory effect of human adipose tissue-derived adult stem cells: comparison with bone marrow mesenchymal stem cells. Br J Haematol 129, 118, 2005.

119. McIntosh, K., Zvonic, S., Garrett, S., Mitchell, J.B., Floyd, Z.E., Hammill, L., Kloster, A., Di Halvorsen, Y., Ting, J.P., Storms, R.W., Goh, B., Kilroy, G., Wu, X., and Gimble, J.M. The immunogenicity of human adipose-derived cells: temporal changes in vitro. Stem Cells 24, 1246, 2006.

120. De Ugarte, D.A., Alfonso, Z., Zuk, P.A., Elbarbary, A., Zhu, M., Ashjian, P., Benhaim, P., Hedrick, M.H., and Fraser, J.K. Differential expression of stem cell mobilization-associated molecules on multi-lineage cells from adipose tissue and bone marrow. Immunol Lett 89, 267, 2003.

121. Mehlhorn, A.T., Niemeyer, P., Kaiser, S., Finkenzeller, G., Stark, G.B., Sudkamp, N.P., and Schmal, H. Differential expression pattern of extracellular matrix molecules during chondrogenesis of mesenchymal stem cells from bone marrow and adipose tissue. Tissue Eng 12, 2853, 2006.

122. Afizah, H., Yang, Z., Hui, J.H., Ouyang, H.W., and Lee, E.H. A comparison between the chondrogenic potential of human bone marrow stem cells (BMSCs) and adiposederived stem cells (ADSCs) taken from the same donors. Tissue Eng 13, 659, 2007.

123. Kim, Y., Kim, H., Cho, H., Bae, Y., Suh, K., and Jung, J. Direct comparison of human mesenchymal stem cells derived from adipose tissues and bone marrow in mediating neovascularization in response to vascular ischemia. Cell Physiol Biochem 20, 867, 2007.

124. Peterson, B., Zhang, J., Iglesias, R., Kabo, M., Hedrick, M., Benhaim, P., and Lieberman, J.R. Healing of critically sized femoral defects, using genetically modified mesenchymal stem cells from human adipose tissue. Tissue Eng 11, 120, 2005.

125. Prichard, H.L., Reichert, W.M., and Klitzman, B. Adult adipose-derived stem cell attachment to biomaterials. Biomaterials 28, 936, 2007.

126. Shen, F.H., Zeng, Q., Lv, Q., Choi, L., Balian, G., Li, X., and Laurencin, C.T. Osteogenic differentiation of adiposederived stromal cells treated with GDF-5 cultured on a novel three-dimensional sintered microsphere matrix. Spine J 6, 615, 2006.

127. Cowan, C.M., Shi, Y.Y., Aalami, O.O., Chou, Y.F., Mari, C., Thomas, R., Quarto, N., Contag, C.H., Wu, B., and Longaker, M.T. Adipose-derived adult stromal cells heal criticalsize mouse calvarial defects. Nat Biotechnol 22, 560, 2004.

128. Hattori, H., Masuoka, K., Sato, M., Ishihara, M., Asazuma, T., Takase, B., Kikuchi, M., Nemoto, K., and Ishihara, M. Bone formation using human adipose tissue-derived stromal cells and a biodegradable scaffold. J Biomed Mater Res B Appl Biomater 76, 230, 2006.

129. Kakudo, N., Shimotsuma, A., Miyake, S., Kushida, S., and Kusumoto, K. Bone tissue engineering using human adipose-derived stem cells and honeycomb collagen scaffold. J Biomed Mater Res A 84, 191, 2008.

130. Scherberich, A., Galli, R., Jaquiery, C., Farhadi, J., and Martin, I. Three-dimensional perfusion culture of human adipose tissue-derived endothelial and osteoblastic progenitors generates osteogenic constructs with intrinsic vascularization capacity. Stem Cells 25, 1823, 2007.

131. Wei, Y., Hu, Y., Hao, W., Han, Y., Meng, G., Zhang, D., Wu, Z., and Wang, H. A novel injectable scaffold for cartilage tissue engineering using adipose-derived adult stem cells. J Orthop Res 26, 27, 2008.

132. Jin, X., Sun, Y., Zhang, K., Wang, J., Shi, T., Ju, X., and Lou, S. Ectopic neocartilage formation from prediffer- 
entiated human adipose derived stem cells induced by adenoviral-mediated transfer of hTGF beta2. Biomaterials 28, 2994, 2007.

133. Jin, X.B., Sun, Y.S., Zhang, K., Wang, J., Shi, T.P., Ju, X.D., and Lou, S.Q. Tissue engineered cartilage from hTGF beta2 transduced human adipose derived stem cells seeded in PLGA/alginate compound in vitro and in vivo. J Biomed Mater Res A 86, 1077, 2007.

134. Betre, H., Ong, S.R., Guilak, F., Chilkoti, A., Fermor, B., and Setton, L.A. Chondrocytic differentiation of human adipose-derived adult stem cells in elastin-like polypeptide. Biomaterials 27, 91, 2006.

135. Dragoo, J.L., Carlson, G., McCormick, F., Khan-Farooqi, H., Zhu, M., Zuk, P.A., and Benhaim, P. Healing full-thickness cartilage defects using adipose-derived stem cells. Tissue Eng 13, 1615, 2007.

136. Rubio, D., Garcia-Castro, J., Martin, M.C., de la Fuente, R., Cigudosa, J.C., Lloyd, A.C., and Bernad, A. Spontaneous human adult stem cell transformation. Cancer Res 65, 3035, 2005.

137. Rubio, D., Garcia, S., De la Cueva, T., Paz, M.F., Lloyd, A.C., Bernad, A., and Garcia-Castro, J. Human mesenchymal stem cell transformation is associated with a mesenchymal-epithelial transition. Exp Cell Res 314, 691, 2008.

138. Rubio, D., Garcia, S., Paz, M.F., De la Cueva, T., LopezFernandez, L.A., Lloyd, A.C., Garcia-Castro, J., and Bernad, A. Molecular characterization of spontaneous mesenchymal stem cell transformation. PLoS ONE 3, e1398, 2008.
139. Zannettino, A.C., Paton, S., Kortesidis, A., Khor, F., Itescu, S., and Gronthos, S. Human mulipotential mesenchymal/ stromal stem cells are derived from a discrete subpopulation of STRO-1bright/CD34/CD45(-)/glycophorin-A-bone marrow cells. Haematologica 92, 1707, 2007.

140. Kaiser, S., Hackanson, B., Follo, M., Mehlhorn, A., Geiger, K., Ihorst, G., and Kapp, U. BM cells giving rise to MSC in culture have a heterogeneous CD34 and CD45 phenotype. Cytotherapy 9, 439, 2007.

141. Peiffer, I., Eid, P., Barbet, R., Li, M.L., Oostendorp, R.A., Haydont, V., Monier, M.N., Milon, L., Fortunel, N., Charbord, P., Tovey, M., Hatzfeld, J., and Hatzfeld, A. A subpopulation of high proliferative potential-quiescent human mesenchymal stem cells is under the reversible control of interferon alpha/beta. Leukemia 21, 714, 2007.

Address reprint requests to: Manuela E. Gomes, Ph.D. 3B's Research Group Department of Polymer Engineering University of Minho Braga 4710-057 Portugal

E-mail: megomes@dep.uminho.pt

Received: July 23, 2008 Accepted: December 8, 2008 Online Publication Date: January 27, 2009 
